\title{
Budget reforms in times of austerity: A centralization cas- cade in Danish central government?
}

\author{
Mads Bøge Kristiansen, postdoc, ph.d., \\ Department of Political Science, University of Copenhagen \\ Øster Farimagsgade 5, 1353 Copenhagen K, Denmark \\ E-mail: mkr@ifs.ku.dk
}

Paper prepared for 20th Annual Conference of the IRSPM, China City University of Hong Kong and The Polytechnic University of Hong Kong; April 13-15, 2016.

Panel G104: Public Management in Times of Austerity

This is a very early draft please do no not quote without the author's permission

\begin{abstract}
In the literature times of austerity is argued to give rise to centralization of decisions making. A recently published article finds evidence of a centralization cascade in times of austerity. Based on a case study of recent changes of the Danish budget institutions, the aim of this paper is to explore how such a centralization cascade may look like when zooming into a specific case. Another aim is to explore the consequences of the changes of budget institutions. The paper shows that the fiscal crisis was a window of opportunity for the Ministry of Finance to introduce a budget reform that centralizes decisions making. A centralization cascade is identified, as the Ministry of Finance enhances more power and control the ministries more frequent and more in the depth, as a result of this parent ministries have to control their agencies more frequent and much more detailed than before, which finally results in a more detailed control and steering carried out by the managing directors in the agencies. The paper also shows that the changes imply a range of consequences; some are functional others are more dysfunctional. There seems therefore to be a lot of trade-offs when budget institutions are designed. The implication hereof is that it is very important to consider all these trade-offs when budget institutions are designed and to consider whether it is possible to design budget institutions so that the dysfunctional consequences are minimized and the functional are kept?
\end{abstract}




\section{Introduction}

Since the global financial crisis of 2007-09 hit the global economies, the world has experienced an enormous decrease of wealth. The impact of the crisis was severe by many measures and reached bigger proportions than any other crisis in more than 70 years (Lin \& Treichel, 2012: 10). The global financial crisis and the subsequent economic crisis led governments to take economic recovery measures, whereupon the increasing debts and budget deficits together again led to a fiscal crisis (Kickert, 2012; Kickert \& Liiv, 2015). This pressure on public finances may be followed by cutbacks and public management reforms including reforms of budget institutions.

Existing theoretical discussions and the experiences of previous fiscal crises, have shown that times of austerity gives rise to centralization of decision making in the public sector (Peters, Pierre \& Randma-Liiv 2011; Behn, 1985; Di Mascio, Natalini \& Stolfi, 2013; Molander, 2001; Raudla, 2013; 2014). In a recently published article Raudla et al. (2015) show the interlinkages between shifts toward more centralized decisions making. Based on a survey of thousands of public sector executives in 17 European countries they find evidence of a centralization cascade, such that centralizing one element of the decision-making process leads to greater centralization throughout the system. The findings in this study generally match the expectations set in the literature, that decision-making processes become more centralized during times of crisis. Thus, respondents reported in the survey that the power of politicians, the Ministry of Finance, and organizational budget units tended to increase during the crises, and decisions making within government organizations tended to become more centralized.

These very interesting findings of a centralization cascade in times of austerity are based on correlations of the perceptions of top public managers based on survey responses. It is therefore interesting to explore the dynamics of these centralizations cascades more in the depth through a case study of changes in budget institutions in a single country. Thus, this paper focuses on recent changes of the budget institutions in Denmark through the introduction of a Budget Law and new requirements for financial management and accounting that together resulted in a regime shift in the Danish budget institutions. The aim of the paper is to get more insight in how such a centralization cascade may look like when zooming into a specific case, and which mechanisms that are leading to it. Another aim is to explore how these changes of the budget institutions may affect organizational behavior and/or their consequences, as the findings of centralization cascades do not in itself say much about, how behavior are affected and the consequences of the reform. Thus, in this paper the following research questions are covered: How are the Danish budget institutions changed in times of austerity, and do they lead to centralization? What are the potential (behavioural) consequences of the changes? 
The changes of the Danish budgetary institutions in times of austerity are analysed on the basis of the literature on budget institutions. An analytical framework based on the budgetary literature primarily as presented by Raudla $(2013 ; 2014)$ and Schick $(2010)$ is deduced. The analytical framework gives an overview of various forms of budget institutions and their impact on budgetary outcomes (Raudla, 2014: 1). The empirical basis is documents e.g. government reports and interviews with civil servants who have either designed or implemented the initiatives included in the new Danish budget regime.

The paper is structured in seven sections. Section two looks into the literature on budgetary institutions, and section three outlines the research method. In section four the Danish budget institutions are presented as they appeared before the recent changes. After this, the recent changes of the budget institutions are presented in section five, and it is analysed whether and how the changes of budgetary institutions lead to a more centralized decisions making. Section six discusses the consequences and trade-offs of the recent changes of the budget institutions, and section seven holds the conclusions and reflects on what can be learned from the analysis.

\section{Designing budget institutions}

The literature on budget institutions focuses on the problems of 'collective action' (von Hagen 2007, Hallerberg et al. 2007, Hallerberg et al. 2009). The literature especially focuses on the common pool problem of public finance (von Hagen 2007), which refers to the problem that the sum of net benefits of public spending for each group of beneficiaries is higher than the benefits for society as a whole. As a result hereof spending-wishes typically exceeds the 'pool' of expenditure that society is willing to fund (von Hagen 2007: 28; Sørensen, Hansen \& Kristiansen, 2016).

According to Schick (2010: 2) rules have a positive impact on fiscal outcomes. Therefore establishing rules seems to be an appropriate measure to improve the fiscal outcomes and solve the common pool problem although it is difficult to discern whether the positive impacts are due to political commitment, or to the constraints imposed by the rules (Schick, 2010: 2). Thus, in the literature it is discussed how budget institutions can be designed in order to solve the common pool problem (e.g. Stolfi, 2010). The main solution offered here is to centralize budgeting through institutional reforms. These reforms may focus on three types of budgetary institutions; 1) rules concerning the transparency and comprehensiveness of budgeting 2) fiscal targets or rules, 3) budgetary procedures (Alesina \& Perroti 1996, von Hagen 2007). In the 
following section we look into various forms of fiscal rules and design principles for budget process rules.

\section{Fiscal rules: Various forms, consequences and trade-offs}

Fiscal rules constrain key budget aggregates that can apply to the deficit or the debt, to total revenues or to other aggregates (Schick, 2010: 2). Raudla (2014: 2) argues that fiscal rules can influence fiscal policy by enhancing the accountability of policymakers and by mitigating the common-pool problems inherent in budgetary decision-making. As fiscal rules establish clear targets with which actual policies can be compared, they may enhance the accountability of the legislature and the executive.

According to Raudla (2013: 34) fiscal rules should be well defined, transparent, simple, flexible, adequate, enforceable, consistent, and efficient. These are many and sometimes quite contrasting criterions. As a result hereof no fiscal rule will be able fully to combine all these features, and a range of trade-offs - that may affect the effectiveness of the fiscal rules - will occur (Raudla, 2013: 34). An important trade-off is between simplicity and flexibility. Related to this trade-off, Schick (2010: 3-6) argues that the recent crisis has questioned the credibility of what he refers to as 'first-generation' rules that rely on simple targets without distinguishing between periods of economic growth and decline. The crisis may therefore be a driver for the introduction of 'second-generation' fiscal rules that are more flexible and take economic cycles into account etc.

Besides a numerical constraint a robust fiscal institution should according to Schick (2010: 1314) include means of enforcing the constraint both ex ante (through monitoring) and ex post (through penalties or intervention). At least three different enforcement models may be adopted: 1) A framework model that builds enforcement into the recurring process of setting targets, compiling the budget, and implementing expenditure plans; 2) Delegation of enforcement responsibility to a supranational authority; 3) Empowering an independent agency within the country to manage the rule-making and enforcing processes.

In the analysis these various forms of fiscal rules will be used as a basis for the interpretation of how fiscal rules have been changed in Denmark in times of austerity (what kind of fiscal targets are adopted), is it first-generation or second-generation rules, how are they enforced, and what are the consequences hereof related to the trade-offs presented above?

\section{Budget process rules}

Budget process rules entail procedural aspects of public budgeting, as they establish the com- 
petencies of the actors involved in the budget process and outline the procedures that govern the preparation, adoption, and implementation of the budget. As it was the case with the fiscal rules, the budget process may also help to solve the common-pool problems of budgeting. In the literature two different kinds of designs of budget process rules are presented: centralized or fragmented (Raudla, 2014: 5). In times of austerity budget institutions are expected to change towards more centralization, as a centralized process is expected to enhance fiscal discipline, whereas a fragmented process is expected to give rise to excessive spending and deficit (Raudla, 2014: 5).

Centralization can occur at various phases of the budget process; 1 ) the planning and drafting of the budget by the executive, 2 ) the adoption of the budget by the parliament, and 3 ) the implementation of the budget (Raudla, 2014: 6). The three phases are further outlined below and it is described which elements that will promote respectively a fragmented and a centralized budget process. This description will serve as important indicators in the analysis of whether and how the changes of the budget institutions lead to centralization.

Phase 1: The planning and drafting of the budget by the executive:

This planning phase may be seen as centralized, when it promotes the setting of spending and deficit (or surplus) targets at the outset, whereas it is fragmented, when the resulting budget is merely a sum of uncoordinated bids from individual ministries (Raudla, 2014: 6).

\section{Phase 2: The legislative approval phase}

The approval phase is centralized when the executive has an important role in setting the agenda of budget proceedings in the legislature, limit legislative amendments to the budget, require amendments to be offsetting, postulate the legislature to vote on the total budget size before the approbation of single provisions, and raise the political stakes of rejecting the executive's budgeti (Raudla, 2014: 6).

\section{Phase 3: The implementation phase}

The implementation phase is centralized when it is difficult to change the existing budget document during the fiscal year, when transfers of funds between chapters are forbidden or limited, and when unused funds cannot be carried over to the next year's budget, when the finance minister has extensive powers to monitor and control spending flows during the fiscal year and sanctioning the disbursement of funds (Raudla, 2014: 6). In the literature it is assumed that elements of centralization will assure that the adopted budget will actually be the basis for the spending decisions of the executive. 
In the analysis these design principles will be used as a basis for the interpretation of how budget process rules have been changed in Denmark in times of austerity, and whether they are followed by centralization. As the fiscal rules and budget process rules structure the incentives of the different actors involved in the budget process and how they influence the actors' interactions and the adjustments in their behavior (Raudla, 2014: 1) it will moreover be discussed what the consequences of the recent changes are.

\section{Research method}

Based on the analytical framework presented above, it is analysed what kind of changes of the budget institutions that are introduced with the Budget Law and the new requirements for financial management and accounting that represent some of the most essential changes of the Danish budget and financial management system for decades.

The analysis focuses primarily on central government although many of the analysed budget institutions are also tailored towards the regions and municipalities in Denmark with the purpose of affecting the fiscal outcomes. The analysis focuses on changes of the fiscal rules and changes of the budget process. The analysis of changes of the budget process will, however, primarily focus on the implementation phase, but will briefly touch upon the planning and drafting of the budget by the executive, whereas the legislative approval phase is not in focus in this paper. This is because the empirical data primarily consists of documents and interviews with executives in central government ministries that were focused on the implementation phase.

\section{Operationalization}

In order to measure how the budget institutions were changed, and whether they are changed towards more centralized decisions making we need an operationalization of fiscal rules and budget process rules. Related to fiscal rules and budget process rules a range of questions are raised on the basis of the analytical framework outlined above.

\section{Fiscal rules}

When the fiscal rules are in focus it is asked; what kinds of fiscal rules are introduced (1) deficit rules, 2) debt rules, 3) expenditure rules, and 4) tax revenue rules)?; are they first- or second-generation rules?; how are the fiscal rules enforced?; do the fiscal rules enhance accountability and may they solve the common pools problem?; are any trade-offs related to these fiscal rules identified? 


\section{Budget process rules}

When it comes to the budget process rules a range of questions are asked to different phases of the budget process. Related to the planning and drafting phase, it is asked whether a target is promoted at the outset, or whether the budget is a sum of uncoordinated bids from the ministries?

Related to the implementation phase it is asked whether it is difficult to change the existing budget document or to adopt supplementary budgets during the fiscal year?; whether unused funds cannot be carried over to the next year's budget?; whether the Minister of Finance has received extensive powers to monitor and control spending flows during the fiscal year and sanctioning the disbursement of funds?; and finally what are the consequences?

On the basis of the questions asked to each phase it is analyzed whether the recent changes point in the direction of centralization or fragmentation, and whether potential dysfunctional consequences or trade-offs related to the changes of the budget institutions are identified.

\section{Data and research strategy}

The analysis is based on documentary material such as ministerial circulars, reports and guidelines etc. and interviews with civil servants who designed or implemented the initiatives. The paper focuses solely on central government. Interviews were carried out in 15 ministries. Because most of the ministries chose to send more than one person, 28 civil servants were interviewed. The interviews were carried out from January to April 2013. In 2015 these interviews were followed up by a new round of interviews in three ministries in order to examine whether the patterns found in the first round of interviews still gave an appropriate picture of the fiscal rules and the budget process after the changes ${ }^{\mathrm{iii}}$. The group of informants included a permanent secretary, several heads of divisions, a managing director in an agency, and heads of departments and employees in departments with responsibility for financial management, budgets and planning. The interviews focused on how the budget institutions were changed with the adoption of the reform initiatives and the potential consequences of these.

The interviews were coded with point of departure in the theoretical framework. Based on the analytical framework indicators for fiscal rules (and trade-offs between various forms of fiscal rules) and for budget process rules (and for various designs of process rules and whether they are pointing in the direction of centralization or fragmentation) were deduced. In the analysis quotations are used in order to illustrate how the changes of the budget institutions affects centralization and how this centralization takes place, as well as they are used as the basis for a discussion of the consequences of these changes. 


\section{Budget institutions in Denmark before the crisis}

Historically legal stipulations applying to the national budgetary procedure were intentionally sparse. The Constitution simply states that all expenditures must be decided through ordinary or extraordinary budget legislation procedures: that no taxes can be levied without legal mandate; that the budget proposal must be presented to parliament no later than four months before the budget year, and that the accounts must be presented to parliament no later than six months after the budget year (Jensen \& Fjord, 2010). The portfolio principle - also stated in the Constitution - emphasises the autonomy of the minister relative to other ministries and establishes limits for coordination across ministerial fields. The Ministry of Finance coordinates the budget process in order to solve these coordination problems. The Ministry of Finance has, however, no constitutional role or formal position on which to base its influence and role. Instead it has devised its roles from institutional practices and the imposition of its authority at crucial times (Jensen \& Fjord, 2010).

\section{The Budget Reform 1984-1985}

Before a budget reform in 1984-1985, the Ministry of Finance's budgetary procedure consisted of a detailed control demanding a lot of resources without giving much overview. In 1984-85 a budget reform was launched with the purpose of fixing weaknesses such as inflexibility and a lack of incentives for efficient operation. Ministries and agencies were given increased autonomy and flexibility in budgetary affairs (Ginnerup et al., 2007: 3; Hansen, 2011). Key features of the 1984-1985 budget reform is presented in the table below:

Table? Key features of the 1984-1985 budget reform

\begin{tabular}{|c|c|}
\hline $\begin{array}{l}\text { Reform } \\
\text { instruments }\end{array}$ & Key features \\
\hline Budget ceilings & $\begin{array}{l}\text { - A 'total celling' for each ministry encompassing all expenditure types including } \\
\text { entitlements } \\
\text { - No 'back-stage' reserves to cover additional expenditures } \\
\text { - } \quad \text { Inclusion of consequences for local government the so-called 'extended total } \\
\text { balance principle' } \\
\text { - Net-based budgets introduced }\end{array}$ \\
\hline In-year monitoring & $\begin{array}{l}\text { - Ministries must report status of ceilings in May. September and December to } \\
\text { the Finance Ministry } \\
\text { - Ministries obliged to take steps to counteract upward deviations from the } \\
\text { budget ceiling }\end{array}$ \\
\hline $\begin{array}{l}\text { Savings and carry } \\
\text { forwards }\end{array}$ & $\begin{array}{l}\text { - Unspent appropriations carried forward up to four years, provided anticipated } \\
\text { use specified }\end{array}$ \\
\hline
\end{tabular}




\begin{tabular}{|l|l|}
\hline & $\begin{array}{l}\text { Appropriations carried forward to the following year do not count in the budget } \\
\text { ceiling for that year }\end{array}$ \\
\hline Staff controls & $\begin{array}{l}\text { Detailed scrutiny of single appointments replaced by frame-based system } \\
\text { where controlling only the higher-level appointments } \\
\text { - }\end{array}$ \\
\hline
\end{tabular}

Source: Jensen \& Fjord (2010: 203)

The main element was the annual aggregate targets for expenditures that were established in February-March. The aim was a 'zero growth' regime, measured against the government expenditure level in 1984 (Jensen \& Fjord, 2010: 204). The aggregate target was broken down into so-called 'total ceilings' for each ministry. If the ministry was able to economize resources, it was rewarded through the carryforward system. In-year compliance with the total frame was monitored by Ministry of Finance through a reporting system after which line ministries should regularly report budget performance, and according to which they were obliged to take steps to prevent or repair breaches (Jensen \& Fjord, 2010: 205).

\section{Effectiveness of the 1984-1985 budget reform}

The changes of the budget institutions had a range of functional consequences from a macroperspective as the economic situation was put on the top of the political agenda and the deficit problem was solved. A number of shortcomings were, however, also recorded. First, the fixed annual targets set prior to the budget process depended on political determination and willingness to stick to the initial targets, and after a few years it proved difficult to comply with the targets, as minority governments struggled with finding parliamentary support for a strict fiscal policy, and the ceilings appeared not as fixed as they seemed (Jensen \& Fjord, 2010: 205). Second, reallocation across organizational entities was not aided by the budget reform, as the ceiling system lead to a perception of the budgets as 'properties' of the single ministries (Jensen \& Fjord, 2010: 205). In order to meet this critique, two types of remedies were presented; 1) to imbue targets with formal authority through legislation; and 2) to strengthen incentive structures and minimize information asymmetries through principal-agent-oriented steering systems (Jensen \& Fjord, 2010: 205-206). The idea of a budget law was, however, judged to be politically unrealistic and it never gained ground in the higher echelons of the core executive; at least not until the fiscal crisis hit the Danish public sector.

\section{Changing budget institutions in times of austerity: Towards more cen- tralization?}

As other countries Denmark was hit by the fiscal crisis, the pressure on the public finances increased and public sector reforms were launched e.g. changes in the budget institutions. In 
2012 a Budget Law for the public sector was approved and in 2011 new requirements for financial management and accounting in central government were launched. In the following section the changes of the budget institutions related to these initiatives are outlined and it is analysed whether the changes lead to centralization.

\section{Fiscal rules}

In 2012 a Budget Law and proposed by the minister of Finance and passed by the Parliament. The law came after a period where successive governments had experienced difficulties in controlling public expenditure and where the accession to the EU Fiscal Compact demanded a more responsible fiscal policy. The purpose of the law was to strengthen expenditure control and realise targets for financial and expenditure policy (Finansministeriet, 2012). The law implies that the budget has to be in balance or surplus. For Denmark this means that the annual structural deficit of the public budget can at the maximum amount to $0.5 \%$ of GDP. Exceptions from the structural balance requirement are only allowed in extreme situations such as extraordinary events or economic crises and under the precondition that the temporarily deviation don't bring the fiscal policy on medium term in a hazard. The core requirement in the Fiscal Compact is a significant strengthening compared to the requirement in the Stability and Growth Pact, as the balance requirement sets a limit for the annual structural deficit, whereas the former objectives alone were medium-termed (Finansministeriet, 2012).

Moreover, with the budget law budget ceilings were introduced. The central government ceiling is split into two: one for operating expenses and one for non-cyclical income transfers (e.g. pensions, student grants/loans). These ceilings cover about $60 \%$ of total central government spending. In order to make the automatic stabilizers work and to reduce the risk for the adoption of a fiscal policy that reinforces the economic conjunctures, expenses such as unemployment benefit, cash benefits and operational expenses related to the employment programmes are delimited from the budget ceilings. The ceilings include a rolling four-year period and must be approved by the Parliament. As the ceilings cover a four-year period they may enhance a more long-term oriented perspective increasing the possibility for the realization of the medium-term objective. When reforms are adopted consequences are calculated into the mediumtermed projections, which offer an opportunity to adopt higher ceilings.

The fiscal rules may be regarded as what Schick (2010) refers to as second-generation fiscal rules, as they are more sophisticated than simple fiscal rules e.g. defining criterions for deficits (such as the Maastricht criterions). The main problem with the simple rules was that they might prevent macroeconomic stabilization via automatic stabilizers and fiscal stimulus, and therefore might prolong an economic downturn. They may moreover encourage cyclically loose 
fiscal policies in good times as they don't give any guidance about the size of the surpluses the government should run (Raudla, 2013: 35). The fiscal rules introduced with the budget law take macroeconomic stabilization via automatic stabilizers and fiscal stimulus into account, as it requires the fiscal policy to adhere to a structural balance. This means that the calculation of the structural balance includes an assessment of how actual employment deviates from the employment in a neutral situation of conjunctures (the employment gap). Moreover, are expenses such as unemployment benefit, cash benefits and operational expenses related to the employment programmes delimited from the budget ceilings in order to make the automatic stabilizers work. Finally, deviations are allowed in the case of severe economic recessions and other emergencies. The fiscal rules can therefore be interpreted as second-generation fiscal rules.

In addition to the Budget law, the law on the Economic Counciliv and the Environmental Economic Council was changed in order to further strengthen the reliability of the expenditure ceilings (Retsinformation, 2012b). With the amendment to the act, the Economic Council as an independent fiscal institution must assess whether the expenditure ceilings are aligned with fiscal objectives for the public finances (Finansministeriet, 2012: 3). Thus, the Economic Council now has a more prominent role in the appraisal of fiscal and expenditure policies as it annually has to assess: 1 ) the sustainability of the public finances in the long term; 2 ) the mediumtermed development in the public budget balance including the development in the structural balance; 3) whether the approved ceilings match the objectives for the fiscal policy; 4) whether the approved expenditure ceilings are being observed in the planning phase ex ante as well as when the accounts are available ex post (Retsinformation, 2012b; Finansminsiteriet, 2012). Moreover, related to the budget proposal for the following year the Economic Council controls expenses outside the ceilings, whether they agree with the government's prognoses and estimations, whether financing is concrete and decided, whether the total amount of expenses are below the ceilings, and whether the ceilings are aligned with the public finances. This assessment is expected to contributing to a qualified and nuanced debate concerning the budget ceilings. In short, with the recent changes the Economic Council has received competencies and capacity to act as watchdog giving second opinions on the projections (that serves as the basis for the establishment of the budget ceilings) of the government. This is in line with Schick's third model to enforce the fiscal rules, as an independent agency is empowered to manage the rule-making and enforcing processes, and as the Economic Council has responsibility to give a second opinion of macroeconomic assumptions and projections etc.

All in all the recent changes of the fiscal rules mean that decisions making has become more centralized as a clear target for the structural balance is established and as budget ceilings are 
approved by the parliament and adopted in law. In addition to the centralization of decisions making accountability also seems to be enhanced as a clear target is set out, which makes it possible to hold the government and supporting parties accountable, and as the Economic Council enforces the fiscal rules.

\section{Budget process rules}

Besides changing the fiscal rules the budget law also changes the budget process. In the following we briefly touch on the planning and drafting phase, and dig more into the deep in the implementation of the budget.

In the planning and drafting phase the budget process changes as a target in the form of the budget ceilings is promoted at the outset. The negotiation process in itself is not changed, but now there is a clear target before the negotiations begins. As mentioned above it changes the decision process towards becoming more centralized.

The budget law also changes the budget process related to the implementation. First, the budget law introduces a correction mechanism that is activated in case of deviations. Each year in August the Minister of Finance has to make up the structural balance for the following fiscal year. If the Minister of Finance's control indicates a fundamental deviation ( $>0.5 \%$ of GDP) of the balance requirement, a corrective action must be carried out (Finansministeriet, 2012: 6; 2014; 2016).

Second, related to the Budget Law, the Ministry of Finance introduced a range of new requirements for financial management and accounting at the end of 2011 (Moderniseringsstyrelsen, 2011). The purpose of these requirements was to ensure that spending ceilings were being observed and to increase opportunities for prioritising resources (Finansministeriet, 2012). The requirements includes:

1. A shared basis of figures and budget transparency. Agencies have to feed a core budget into the shared financial system. This must reflect the agency's internal budget at an aggregated level. Thereby a basis for a permanent reporting frame for the expenditure control during the year is established.

2. Periodizing. The core budget and the forecast for spending throughout the year must be periodized in months or quarters depending on the type of appropriation and a risk assessment. This increases transparency, establishes a more precise basis for the budget, and makes it possible to identify deviations between budget and spending.

3. Standard cadences for budget and accounting control focusing on explaining deviations and describing corrective action if relevant (Moderniseringsstyrelsen, 2013; Hansen \& Kristian- 
sen, forthcoming).

Finally, at the end of 2012 a new rule related to allocation of savings was presented (Retsinformation, 2012a; Finansministeriet, 2014; 2016) by the Ministry of Finance, in which it was stated that a specific agency to spend savings must have approval from its parent ministry, and that net spending of savings must be neutral or negative in total for the minister's range of portfolio in the fiscal year ${ }^{v}$. Thus, the implementation phase also changes in several ways with the introduction of the budget law and the new requirements for financial management leading to centralization.

First of all, the Ministry of Finance's power for controlling the ministries was enhanced with the recent changes. The frequency for reporting and the amount of information regarding spending developments reported from each of the ministries to the ministry of Finance were extended as an extra spending report and a quite comprehensive amount of reporting requirements were introduced (Moderniseringsstyrelsen, 2013). Therefore, more information will flow to the Ministry of Finance, which presumably will increase the Ministry of Finance's oversight of the ministries' operations, reduce the level of information asymmetry and enhance the Ministry of Finance's position as expenditure guardian: "The Ministry of Finance gains a better insight into the priorities that normally were the ministries' own responsibility" (R9). The Minister of Finance's coordination responsibility is moreover strengthened, because expectations related to reduced spending of savings must be reported to the Ministry of Finance in the spending control for the purpose of redistribution (Retsinformation, 2012a).

The Ministry of Finance also has received more leeway for sanctioning. If the Minister of Finance's spending control during the fiscal year shows indications of central government expenditure ceilings not being observed, counter arrangements must be launched. If there is a risk of exceeding the central government expenditure ceiling, the Minister of Finance is obliged to carry out initiatives preventing this. In addition, the Minister of Finance must carry out a subsequent spending control after the end of the year. If the central government expenditure ceiling is exceeded, a reduction in its ceiling for the following year corresponding to the excess has to be implemented (Finansministeriet, 2012: 8).

To sum up, the recent changes of the budget institutions are followed by an increasing centralization, and the Ministry of Finance is given more power relatively to the line ministries. Centralization in the relationship between Ministry of Finance and the ministries leads moreover to centralization in the relation within ministries (between departments and agencies), as the principal-agent relations are strengthened and clarified by the approval of core budgets and 
forecasts, and not least in the budget and accounting control that must be presented for the agency management and approved in the parent ministry. The permanent secretary must moreover sign the spending reports, which also underlines a centralization of decisions making and a new and changed role for the parent ministry: "We have to play a much more active role, we now have to enter the engine room in each single agency" (R9).

In the spending reports the parent ministry must assess whether the ministry's final accounts are expected to exceed the appropriations for the fiscal year, and find specific financing within the ministry if the prior spending control shows that the appropriations are likely to be exceeded. "Now we (the parent ministry) need to steer more centrally [...], who spend less, and who will be able to spend some of their savings etc." (R16). The result hereof is that the parent ministry must coordinate across the ministry's portfolio, and if necessary reorder priorities in order to ensure that net spending of savings is reduced to zero (Retsinformation, 2012a). Thus, the demand for centralized decisions making and information within the minister's range of portfolio has increased, and parent ministries have to move closer to the operations in its agencies: "The steering relations between parent ministries and agencies changes and become more intense, as we (parent ministries) become some kind of a bank manager" (R27) (Hansen \& Kristiansen, forthcoming).

All in all the changes of the Danish budget institutions in times of austerity show a centralization of decisions making, as a clear target in the form of budget ceilings is promoted at the outset delimiting the possibilities for the legislative to add budget proposals beyond the ceilings, and as the implementation of the budget becomes more centralized in a range of processes during the fiscal year. Moreover, the analysis illustrates how a centralization cascade may look like; The Ministry of Finance enhances more power and control the ministries more frequent and more in the depth, as a result of this the parent ministries have to control there agencies more frequent and much more detailed than before, which results in a more detailed control and steering carried out by the managing directors in the agencies.

\section{What are the consequences of the changed budget institutions?}

As presented above the changes of budget institutions in times of austerity leads to a more centralized budget process. In this section the consequences and the trade-offs hereof are discussed.

\section{Fiscal rules: Consequences and trade-offs}

In the presentation of the budget law (Finansministeriet, 2012) it was argued that the budget 
law and the approval of budget ceilings by law in the parliament (Folketinget) would create a clear political obligation to keep within the ceilings year after year and result in a broad political support of the new budget regime. Observers argue that the introduction of the budget ceilings has limited the 'playing field' for the politicians in parliament when the budget is negotiated. As a target is promoted at the outset it delimits the number of budget requests that may be suggested during the annual budget negotiations. Thus, the Budget Law establishes a credible commitment, which may improve the possibility of ensuring that public expenditures can be controlled even when economic conditions improve and public expenditure preferences rise (Suenson, Nedergaard \& Christiansen, 2016). The recent changes mean that the fiscal rules have become more centralized and that accountability is enhanced. It is no longer possible for the legislative to break the budget ceilings without being seen as economic irresponsible. A result of this may be that it may become possible to solve the common pool problem. Thus, the centralization that follows the recent changes in the Danish budget institutions seems very appropriate in order to meet the fiscal target, create accountability and solve the common pool problem. Despite these seemingly functional consequences, the recent changes of the budget institutions may also make the decision process more technocratic. A lot of decisions making is given to the civil servants in the Ministry of Finance that calculate the structural balance and the level of the budget ceilings, and thereby also the level of public expenditures.

As argued above the recent changes of fiscal rules in Denmark may be regarded as secondgeneration fiscal rules, as they are more sophisticated than simple fiscal rules e.g. defining criterions for deficits. Despite that the adoption of second-generation fiscal rules means that macroeconomic stabilization via automatic stabilizers and fiscal stimulus are taking into account, it may be a problem that the rules have become too sophisticated. The result of too sophisticated fiscal rules may be that the electorate can't serve as the main enforcement mechanism, as they will not be capable to evaluate whether the government has complied with the fiscal targets. Neither seems the legislative to be able to hold the government accountable for its fiscal policy. Thus, the executive and the Ministry of Finance's power seems to have increased significantly, as only very few persons are able to understand these calculations: "It is so complicated that only very few have the insight to assess these things" (R31). As a result of this a number of Danish Economists have criticised the Ministry of Finance for 'hiding' how the structural balance is calculated. They argue that the way the structural balance is calculated is opaque, which is making a democratic control impossible. This gives the government and the Ministry of Finance an opportunity to adjust the structural balance to fit the current political agenda of the government (Pedersen \& Praefke, 2015). 
In order to enforce the fiscal rules, the Economic Council, as an independent fiscal council, has, however, received new competencies and capacity to control the government. The use of independent fiscal councils as an institutional device to enforce fiscal rules is argued, at least theoretically, to be the most attractive enforcement mechanism (Raudla, 2013: 36). The unit in the Economic Council enforcing the fiscal rules is, however, relatively small, and there is a considerable capacity asymmetry compared to the Ministry of Finance. Moreover, after the election in 2015, the change of government, and the following ministerial reorganization, the Economic Council became a part of and subordinated to the Ministry of Finance. This might potentially - at least theoretically - give some interest conflicts, although the Economic Council is legally independent and have their own executive board. The Economic Council could also - theoretically - contribute to economic policy discussions in the public sphere and raise the level of public debate on macro-economic issues (Raudla, 2013: 36). The issues debated are, however, so complex that not even the countries' best economists agree on how the structural balance should be calculated, and on what the structural balance amount to at a specific time.

In the fall 2015 the Economic Council (Det Økonomiske Råd, 2015) presented in their biannual report a more positive assessment of the fiscal situation than the newly elected government and the Ministry of Finance had calculated a few months earlier. The Economic Council argued that - without the government's budget proposal - there was a surplus of 0.2 per cent of GDP in 2016, whereas the Ministry of Finance had calculated that there would be a structural deficit of 0.7 per cent of GDP. That is a difference of nothing less than 0.9 per cent of GDP equaling around 17 billion DKK. As a response to this report from the Economic Council, the Ministry of Finance (2015) issued a press statement in which it was said that they were amazed at the Economic Council's assessment, and that they disagreed. Thus, on the one hand the Economic Council may be able to raise the level of public debate on macro-economic issues, which is very appropriate in a democracy. On the other hand when even some of the countries' best economists disagree about what the structural balance actually is at given point in time and how it should be calculated, it becomes very difficult for non-experts to hold the government accountable. In other words, when only very few people are able to understand these very complicated rules, neither the legislative nor the general public may be able to evaluate whether the government has complied with the fiscal rules or not.

\section{Budget process rules}

Many of the changes of the budget process rules also seem to enhance the opportunity of meeting the budget. In order to ensure that ceilings are being observed it seems to be appropriate that net spending in total for the ministry now must be either neutral or negative especially as the Danish agencies in recent years have generated very large savings. If they had 
the opportunity to spend savings, it would be very difficult to ensure that the ceilings were being observed. Therefore, the majority of the informants argued that a lot of the elements in the Budget Law are quite reasonable when seen from a macro political point of view focusing at controlling the expenditures. Moreover, it enhances the opportunity for, or the necessity of, re-allocation of spending possibilities across agencies in a ministry.

Despite this, almost all informants argue that the changed rules for spending savings gives some incentives for dysfunctional behaviour at the organizational level. The fear of sanctions for exceeding the ceilings may lead to caution in spending at the beginning of a year. At the same time the new rules related to the use of savings give incentives for the agencies to spend their entire appropriation before the end of the year, meaning that incentives for practising cost-effectiveness and economise resources vanish. At the end of the year money might therefore be spent on initiatives, which are not strictly necessary. These behavioural changes are described in various ways in the interviews. Some describe it as a kind of "stop-go" management others describe it as "intelligent petrol burning" with a reference to the 1970s before the budget reform in 1984-1985, where the Danish Defence in particular was said to burn off petrol in December to spend the entire budget and avoid cutbacks the following year. In relation to this, several informants argued that the new budget implementation rules lead to a more short-term oriented management, as the main focus is on keeping to the budget framework within a year. The result of this is a decreased flexibility in the spending.

The centralization of the budget processes including the increasing amount and detail of information reported more frequent between various hierarchical levels may also enhance accountability and improve the fiscal discipline throughout the chain of delegation, and improve the possibility for meeting the fiscal targets. Some dysfunctional consequences are, however, also identified, as the informants argued that the new budget process rules includes many unnecessary and too detailed requirements, and the spending control is argued to being too comprehensive, too frequent and too focused on details: "It is a reporting hell in a very detailed way which does not serve any purposes" (R16) (Hansen \& Kristiansen, forthcoming).

\section{Conclusion}

The paper has shown a range of interesting issues. First, the fiscal crisis may be viewed as a window of opportunity for the Ministry of Finance to introduce changes of the budget institutions. For almost two decades the existing budget regime had showed a number of shortcomings. In order to meet these shortcomings it was suggested to imbue targets with formal authority through legislation and to strengthen incentive structures and minimize information asymmetries through principal-agent-oriented steering systems. The idea of a budget law was, 
however, judged to be unrealistic. When the fiscal crisis hit, a window of opportunity opened and it was possible to introduce changes of the budget institutions. The window of opportunity was moreover enabled by the requirements in the Fiscal Compact that paved the way for a budget reform.

Second, the changes of the budget institutions introduced in times of austerity lead to centralization. The changes of the fiscal rules centralized decisions making, as an overall fiscal target such as the structural balance is established, as budget ceilings is approved by law in the parliament delimiting the negotiations process, and as the fiscal rules are enforced by the Economic Council. Thus, as a clear target is promoted at the outset the possibilities for the legislative to add budget proposals beyond the ceilings is delimited. The implementation of the budget was also centralized, as the Ministry of Finance was given more power to monitor and control spending flows during the fiscal year and to sanction overspending, as the opportunity to spend savings was delimited, and as the relation between departments and agencies also was changed towards centralized decisions making and tightened accountability relations. The principal-agent relations were strengthened and clarified by the approval of core budgets and forecasts, and not least in the budget and accounting control. Thus, the Danish case of changes of budget institutions in times of austerity shows centralization, which is similar to other studies of reforms of budget institutions in times of austerity (Peters, Pierre \& Randma-Liiv 2011; Behn, 1985; Di Mascio, Natalini \& Stolfi, 2013; Molander, 2001; Raudla, 2013; 2014; Raudla et al., 2015). The paper has moreover added a more in-depth description of how a centralization cascade looks; the Ministry of Finance enhances more power and control the ministries more frequent and more in the depth, as a result of this the parent ministries have to control their agencies more frequent and much more detailed than before, which results in a more detailed control and steering carried out by the managing directors and budget offices in the agencies.

Third, the changes imply a range of consequences. Some are functional others are dysfunctional, and there seems to be a lot of trade-offs when budget institutions are designed. The centralization that follows the recent changes in the Danish budget institutions seems very appropriate in order to meet the fiscal target, create accountability and solve the common pool problem. A lot of decisions making seems, however, to be delegated to the civil servants in the Ministry of Finance that calculate the structural balance and the level of the budget ceilings. The paper also showed how the crisis were met by the introduction of second generation fiscal rules that are more flexible and sophisticated than first generation fiscal rules. They introduce, however, other problems, as very few persons are able to understand how the structural balance is calculated. Thereby it becomes difficult to evaluate whether the government has com- 
plied with the fiscal target or not, and to hold the government and the Ministry of Finance accountable for the fiscal policy.

Finally, the changes of the budget process rules and the centralization that followed seems on the one hand to enhance transparency, accountability, focus on meeting the budget and the budget discipline. As a result of this it is more likely that the fiscal targets will be met in the future and the Danish economy may be regarded more credible from the outside. On the other hand there seems to be some dysfunctional consequences of the centralization of the budget implementation, as dysfunctional (behavioral) consequences such as "intelligent petrol burning", "stop-go management" or lack of flexibility in the use of the appropriation may be a potential outcome when we focus on the micro-level. Moreover, leads the centralization of the budget implementation to increasing administrative burdens in ministries and agencies.

Based on the analysis, there seems to be a lot of trade-offs when budget institutions are reformed and redesigned. Although the recent changes of the Danish budget institutions to a large extent seems to be in line with suggestions of how budget institutions should be designed post-crisis, several dysfunctional consequences are identified. It raises the question as to whether it is possible to design budget institutions in which the dysfunctional consequences are minimized at the same time as the functional are kept? The implication hereof is that it is very important to consider all these trade-offs when budget institutions are designed. It may be possible to minimize some of the dysfunctional consequences through well-thought designs, whereas other trade-offs may be paradoxes in which you can't find an optimal solution, and will have to choose between different dysfunctions. Another implication may be that evaluations of the consequences of budget institutions should be carried out periodically in order to improve the design and avoid dysfunctional consequences.

\section{References}

Alesina, Alberto og Roberto Perotti (1996): Fiscal discipline and the Budget Process, The American Economic Review, 86(2): 401-407.

Behn, R.D. (1985). Cutback Budgeting. Journal of Policy Analysis and Management, 4(2): 155177.

Det Økonomiske Råd (2013). Dansk Økonomi Efterår 2013. [Danish Economy Autumn 2013]. Albertslund: Rosendahls-Schultz Grafisk.

Det Økonomiske Råd (2015). Dansk Økonomi Efterår 2015. [Danish Economy Autumn 2015 ]. Albertslund: Rosendahls-Schultz Grafisk.

Di Mascio, F., Natalini, A. and Stolfi, F. (2013). The Ghost of Crises Past. Analyzing Reform 
Sequences to Understand Italy's Response to the Global Crisis. Public Administration, 91(1): 17-31.

Finansministeriet (2012). Handouts vedrørende budgetlov. [Handouts concerning the Budget Law]

Finansministeriet (2014). Budgetvejledningen 2014. [Budget instruction 2014]. Albertslund: Rosendal Schultz Information.

Finansministeriet (2015). DØR efterårsrapport 2015. Finansministeriets skriftlige indlæg. Finansminsteriet.

Finansministeriet (2016). Budgetvejledningen 2014. [Budget instruction 2014]. Albertslund: Rosendal Schultz Information.

Ginnerup, R., Jørgensen, T. B., Jacobsen A. M. and Refslund, N. (2007). Performance Budgeting in Denmark. OECD Journal on Budgeting, 7(4): 1-24.

Hansen, H. F., \& Kristiansen, M. B. (forthcoming). Accountability in Times of Austerity: Democratic and Constitutional Gains, but Learning Loss? In P. Lægreid \& T. Christensen "Ashgate Research Companion to accountability and Welfare State reforms in Europe", Ashgate Publishing Limited, Aldershot.

von Hagen, J. (2007). Budgeting Institutions for better fiscal Performance, in Shah, A. (ed). Budgeting and Budgetary Institutions, World Bank.

Hallerberg, M., Strauch, R., von Hagen, J. (2007). The design of fiscal rules and forms of governance in European Union countries, in European Journal of Political Economy, 23: 338-359.

Hallerberg, M., Strauch, R. \& von Hagen, J (2009). Fiscal Governance in Europe, Cambridge U.P.

Jensen, L. \& Fjord, D. (2010): Budget reforms in Denmark: unheralded but nontheless effective, in Wanna, J., Jensen, L. et al. (eds) (2010): The reality of budgetary reform in OECD Nations, trajectories and consequences. Edward Elgar, Cheltenham UK.

Kickert, W. (2012). State Responses to the Fiscal Crisis in Britain, Germany and the Netherlands. Public Management Review, 14(3), 299-309

Kickert, W., Randmaa-Liv, T. (2015). Europe Managing the Crisis. The Politics of Fiscal Consolidation, Routledge.

Lin, J.Y. \& Treichel, V. (2012). The Unexpected Global Financial Crisis: Researching Its Root Cause. Policy Research Working Paper 5937. Washington D.C.: World Bank

Moderniseringsstyrelsen (2011). Kom godt i gang med de nye krav til økonomistyring i 2012. Vejledning til Projekt god økonomistyring i den offentlige sektor. [Getting well under way with the new requirements for financial management in 2012. Gudiance to project sound financial management in the public sector].

Moderniseringsstyrelsen (2013). Vejledning om budgettering og budget- og regnskabsopfølgning. [Guidance on budgeting and budget and accounting controls]

Molander, P. (2001). Budgeting Procedures and Democratic Ideals. Journal of Public Policy, 21(1): 23-52. 
Pedersen, T. B \& Praefke, K. (2015). Hjort anklages for at mørklægge nøgletal. Børsen 06.10.2015. http://borsen.dk/nyheder/avisen/artikel/11/123038/artikel.html

Peters, B.G. (2011). Governance Responses to the Fiscal Crisis: Comparative Perspectives. Public Money \& Management, 31(1): 75-80.

Peters, G. \&, Pierre, J., Randma-Liiv, T. (2011): Global Financial Crisis, Public Administration and Governance: Do New Problems Require New Solutions? Public Organiz Rev (2011) 11:1327.

Raudla, R. (2013). Budgeting during Austerity: Approaches, Instruments and Practices, Budgetary Research Review 5 (1), 1-10.

Raudla, R. (2014). Budgetary Institutions, Encyclopedia of Law and Economics. DOI 10.1007/978-1-4614-7883-6_517-1

Raudla, R., Douglas, J. W., Randma-Liiv, T. \& Saavi, R. (2015). The Impact of Fiscal Crisis on Decision-Making Processes in European Governments: Dynamics of a Centralization Cascade, Public Administration Review.

Retsinformation (2012a). Cirkulære om afprøvning af budgetlovens bestemmelser $i$ staten $i$ 2013. [Government circular on the testing of the provisions of the Budget Law in central government in 2013]. CIR nr. 85 af 29/11/2012.

Retsinformation (2012b). Lov om ændring af lov om Det Økonomiske Råd og Det Miljøøkonomiske Rad, 2011/1 LSV 167. [Act on the changes of the act on the Economic Council and the Environmental Economic Council].

Schick, A. (2010). Post-Crisis Fiscal Rules: Stabilising Public Finance while Responding to Economic Aftershocks, OECD Journal on Budgeting, Vol. 2010/2

Stolfi, F. (2010). Testing Structuralist and Interpretative Explanations of Policy Change: The Case of Italy's Budget Reform, Governance: An International Journal of Policy, Administration,

Suenson, E. L., Nedergaard, P. \& Christiansen, P. M. (2015). Why do you want to lash yourself to the mast? The case of the Danish "Budget Law", Public Budgeting \& Finance, 36 (1), pp. 321.

\footnotetext{
'This paper draws on empirical material also presented in Hansen, H. F., \& Kristiansen, M. B. (forthcoming) but is reframed and analyzed through another theoretical framework that reframes and adds other dimensions of the material.

ii Contrary it can be described as fragmented when the parliament has the opportunity to make unlimited amendments to the draft budget, spending decisions can be made by legislative committees with narrow and dispersed authorities, and there is little guidance of the parliamentary process by the executive (Raudla, 2014: 6).

iii Data were collected in collaboration with Professor Hanne Foss Hansen.

iv The Economic Council is an economic advisory body headed by a chairmanship consisting of four independent economists and served by a secretariat with approximately 30 employees.

$\checkmark$ Excepted from this rule is use of savings that is placed at specific accounts on the annual budget (Finansministeriet, 2016: 33).
} 